\title{
13. CENOZOIC SILICOFLAGELLATE AND COCCOLITH STRATIGRAPHY, SOUTHEASTERN ATLANTIC OCEAN, DEEP SEA DRILLING PROJECT LEG 40
}

\author{
David Bukry, United States Geological Survey, La Jolla, California
}

\section{INTRODUCTION}

Leg 40 of the Deep Sea Drilling Project, December 1974 to February 1975, which began at Cape Town, South Africa, and ended at Abidjan, Ivory Coast (Figure 1), recovered 248 cores at six drilling sites, 360365. Light-microscope techniques were used to study the Cenozoic silicoflagellates and coccoliths of 212 samples from these cores. Coccolith zonation of the samples, summarized in Figure 2, follows Bukry $(1975 c)$.

\section{SITE SUMMARIES}

Site 360

(lat $35^{\circ} 50.75^{\prime} \mathrm{S}$, long $18^{\circ} 05.79^{\prime} \mathrm{E}$, depth $2949 \mathrm{~m}$ )

Site 360 , on the continental rise of southwest Africa, was cored to obtain a continuous stratigraphic section of the younger portion of the continental rise sediment prism. Coccoliths in the 50 sediment cores $(80$ to $840 \mathrm{~m}$ subbottom) range from lowermost Pliocene or upper Miocene to middle Eocene. Etching and overgrowth of specimens is moderate. The assemblages are temperate in character, and contain cool-water indicators such as persistant Chiasmolithus in the Paleogene, abundant Isthmolithus near the Eocene-Oligocene boundary, and Discoaster challengeri in the Miocene. Low-latitude zonal markers such as Discoaster bifax, D. hamatus, and Sphenolithus ciperoensis are present in small numbers, however, and permit relatively fine zonation.

The Amaurolithus tricorniculatus Zone assemblages of Cores 1 to 4 ( 80 to $118 \mathrm{~m}$ ) are dominated by placoliths, and contain ceratoliths of only two species-Amaurolithus delicatus and A. primus. Discoasters and sphenoliths are sparse and species of Ceratolithus are missing, suggesting a cool-temperate assemblage.

The lower part of the Discoaster berggrenii Subzone in Sample 360-12-3, 49-50 cm (187 m), has Discoaster loeblichii and Minylitha convallis overlapping with Discoaster berggrenii and D. surculus.

Discoasters are scarce or absent in many Oligocene assemblages, such as those of Samples 360-31-3, 49-50 $\mathrm{cm}(492 \mathrm{~m})$ and $360-34-3,49-50 \mathrm{~cm}(549 \mathrm{~m})$. In Sample $360-30-3,9-11 \mathrm{~cm}(472 \mathrm{~m})$, the low ratio of Discoaster to Chiasmolithus $(17 / 83)$ suggests cool-water conditions (Bukry, 1973). This ratio shows a substantial cooling trend through the late Eocene into the Oligocene at Site 360 (Figure 3) which corresponds to that identified by oxygen isotope determinations from the Pacific (Savin et al., 1975).

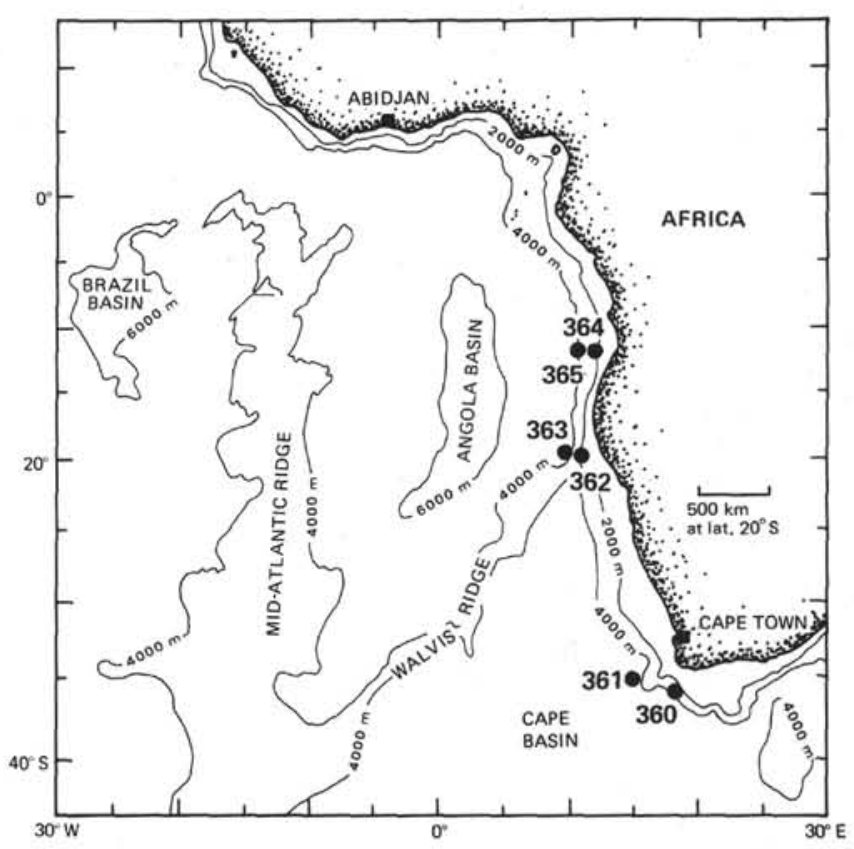

Figure 1. Sketch map of sites drilled on Deep Sea Drilling Project Leg 40.

Chiasmolithus oamaruensis overlaps with C. grandis in Samples 360-39-3, 49-50 cm (633 m) and 360-40-2, $49-50 \mathrm{~cm}(651 \mathrm{~m})$, which are assigned to the lower upper Eocene Chiasmolithus oamaruensis Subzone. The deepest samples examined, 360-49-2, 50-52 cm (812 m) and $360-50-2,49-50 \mathrm{~cm}(832 \mathrm{~m})$, contain the shortranged middle middle Eocene guide fossil Chiasmolithus gigas.

\section{Site 361}

(lat $35^{\circ} 03.97^{\prime} \mathrm{S}$, long $15^{\circ} 26.91^{\prime} \mathrm{E}$, depth $4549 \mathrm{~m}$ )

Site 361 , near the base of the southwest African continental rise west of Cape Town, was cored from upper Eocene at 32 meters subbottom into the Lower Cretaceous at 1314 meters. Coccolith-rich lower Cenozoic sediment was cored discontinuously in the interval 32 to 279 meters (Cores 1 to 10). Upper Eocene and Paleocene specimens are strongly etched; middle and lower Eocene specimens are moderately etched and overgrown.

Upper Eocene assemblages identified by the overlapping ranges of solution-resistant Discoaster saipanensis and Isthmolithus recurvus in Samples 361-1$6,49-50 \mathrm{~cm}(35 \mathrm{~m})$ and $361-2-2,49-50 \mathrm{~cm}(61 \mathrm{~m})$ contain placoliths and placolith remnants that are 


\begin{tabular}{|c|c|c|c|c|c|c|c|}
\hline AGE & ZONE & SUBZONE & 360 & 361 & 362 & 363 & 364 \\
\hline \multirow{5}{*}{ 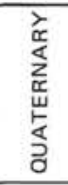 } & \multicolumn{2}{|l|}{ Emiliania huxleyi } & & & $1-1$ & & 1.3 \\
\hline & \multirow{2}{*}{$\begin{array}{c}\text { Gephyrocapsa } \\
\text { oceanica }\end{array}$} & Ceratolithus cristatus & & & $1-3 / 2-3$ & & \\
\hline & & Emiliania ovata & & & & & \\
\hline & \multirow{2}{*}{$\begin{array}{c}\text { Crenalithus } \\
\text { doronicoides }\end{array}$} & Gephyrocapsa caribbeanica & & & & & \\
\hline & & Emiliania annula & & & $3-3 / 4-3$ & & \\
\hline \multirow{7}{*}{$\begin{array}{l}\text { Uू } \\
\text { Uू } \\
\underline{0} \\
\underline{a}\end{array}$} & \multirow{4}{*}{$\begin{array}{l}\text { Discoaster } \\
\text { brouweri }\end{array}$} & Cyclococcolithina macintyrei & & & \multirow{4}{*}{$5 \cdot 3 / 10-3$} & & \\
\hline & & Discoaster pentaradiatus & & & & & \\
\hline & & Discoaster surculus & & & & & \\
\hline & & Discoaster tamalis & & & & & \\
\hline & \multirow{2}{*}{$\begin{array}{l}\text { Reticulofenestra } \\
\text { pseudoumbilica }\end{array}$} & Discoaster asymmetricus & & & $11 \cdot 3 / 12 \cdot 3$ & & \\
\hline & & Sphenolithus neoabies & & & & & $3 \cdot 1 / 3 \cdot 2$ \\
\hline & \multirow{2}{*}{$\begin{array}{l}\text { Amaurolithus } \\
\text { tricorniculatus }\end{array}$} & $\begin{array}{l}\text { Ceratolithus rugosus } \\
\text { Ceratolithus acutus }\end{array}$ & \multirow{2}{*}{$1 \cdot 1 / 4 \cdot 3$} & & $13 \cdot 3$ & & $3 \cdot 6$ \\
\hline \multirow{15}{*}{ 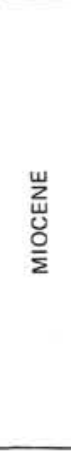 } & & $\begin{array}{l}\text { Ceratolithus acutus } \\
\text { Triquetrorhabdulus rugosus }\end{array}$ & & & 14-3/19.3 & & \\
\hline & \multirow{2}{*}{$\begin{array}{c}\text { Discoaster } \\
\text { quinqueramus }\end{array}$} & Amaurolithus primus & $5 \cdot 3 / 7 \cdot 3$ & & $20-3 / 23-3$ & & \\
\hline & & Discoaster berggrenii & $8 \cdot 3 / 12 \cdot 3$ & & $24 \cdot 3 / 26 \cdot 3$ & & $4 \cdot 2$ \\
\hline & \multirow{2}{*}{$\begin{array}{c}\text { Discoaster } \\
\text { neohamatus }\end{array}$} & Discoaster neorectus & \multirow{2}{*}{$13-3 / 15-2$} & & 27.3 & & $? 4 \cdot 6$ \\
\hline & & Discoaster bellus & & & 29.3 & & \\
\hline & \multirow{2}{*}{$\begin{array}{l}\begin{array}{l}\text { Discoaster } \\
\text { hamatus }\end{array} \\
\end{array}$} & Catinaster calyculus & $16 \cdot 3$ & & & & \\
\hline & & Helicosphaera carteri & & & $30 \cdot 3$ & & \\
\hline & \multicolumn{2}{|l|}{ Catinaster coalitus } & 17.2 & & $31 \cdot 3,732-3$ & & \\
\hline & \multirow{2}{*}{$\begin{array}{c}\begin{array}{c}\text { Discoaster } \\
\text { exilis }\end{array} \\
\end{array}$} & Discoaster kugleri & $? 18-2$ & & 33.3 & & \\
\hline & & Coccolithus miopelagicus & $19-3 / 21-3$ & & $34 \cdot 3$ & $1 \cdot 1 / 1 \cdot 3$ & \\
\hline & \multirow{2}{*}{\multicolumn{2}{|c|}{$\begin{array}{l}\text { Sphenolithus heteromorphus } \\
\text { Helicosphaera ampliaperta }\end{array}$}} & $22 \cdot 6$ & & $35 \cdot 3 / 36 \cdot 3$ & & \\
\hline & & & $23-3$ & & 37.3 & & $5 \cdot 3$ \\
\hline & & emnos & & & & & \\
\hline & & Discoaster druggii & $24 \cdot 2$ & & $? 38.3$ & & \\
\hline & Triquetrorhabdulus & Discoaster deflandrei & & & 39.3 & 1.5 & \\
\hline & & Cyclicargolithus abisectus & $25 \cdot 2$ & & $41 \cdot 3$ & & \\
\hline & Sphenolithus & Dictyococcites bisectus & $26-2 / 28-3$ & & $2 A \cdot 3$ & $2 \cdot 3$ & \\
\hline & ciperoensis & Cyclicargolithus floridanus & $29 \cdot 3 / 30-3$ & & $3 A-3 / 4 A \cdot 1$ & $3 \cdot 2 / 4 \cdot 3$ & \\
\hline Uु & & entus & $31 \cdot 3 / 33 \cdot 3$ & & $4 A \cdot 3 / 5 A \cdot 3$ & $5-3 / 7-1$ & \\
\hline$\underline{0}$ & Sph & stentus & & & & & \\
\hline ठे & Helicosphaera & Reticulofenestra hillae & & & $5 A-5$ & 8.2 & \\
\hline & reticulata & Coccolithus formosus & & & $6 A \cdot 2,6 A \cdot 5$ & & \\
\hline & & Coccolithus subdistichus & $34 \cdot 3 / 35 \cdot 3$ & & ?7A-2 & $9 \cdot 2$ & \\
\hline & Discoaster & Isthmolithus recurvus & $36-1 / 39-2$ & $1.6 / 2.2$ & $7 A-5 / 8 A-3$ & 9.4 & \\
\hline & barbadiensis & Chiasmolithus oamaruensis & $39-3 / 40-2$ & & & & \\
\hline & Reticulofenestra & Discoaster saipanensis & $41 / 2-43 \cdot 2$ & & $9 A-1 / 9 A-4$ & 10.5 & \\
\hline & umbilica & $\begin{array}{c}\text { Discoaster bifax } \\
\text { Coccolithus staurion }\end{array}$ & $\frac{46-2 / 48-2}{48-4}$ & & $\frac{10 A-1}{10 A-3}$ & $\frac{11.1}{11.2}$ & \\
\hline 亗 & $\begin{array}{l}\text { Nannotetrina } \\
\text { quadrata }\end{array}$ & $\begin{array}{l}\text { Chiasmolithus gigas } \\
\end{array}$ & $49 \cdot 2 / 50-2$ & & $11 \mathrm{~A} \cdot 1$ & $\begin{array}{l}111.2 \\
11.5\end{array}$ & \\
\hline 嵌 & & Discoaster strictus & & $5 \cdot 1$ & & & \\
\hline 品 & Discoaster & Rhabdosphaera inflata & & $5.4 \& 7.1$ & & $12 \cdot 2$ & \\
\hline & sublodoensis & Discoasteroides kuepperi & & & & 12.5 & $8-1$ \\
\hline & & nsis & & $5 \cdot 6 / 6-2$ & $12 \mathrm{~A}-1$ & 13-2/13-5 & $8 \cdot 3$ \\
\hline & Discoaster & $\begin{array}{l}\text { stylus } \\
\text { Discoaster binodosus }\end{array}$ & & $8 \cdot 1$ & & & 8.5 \\
\hline & diastypus & Tribrachiatus contortus & & & & $14 \cdot 2$ & $9-1$ \\
\hline & Discoaster & Campylosphaera eodela & & $8-6 / 9 \cdot 2$ & & $14-5 / 15-3$ & $9-3$ \\
\hline & multiradiatus & Chiasmolithus bidens & & & & & \\
\hline & & & & & & & \\
\hline ¿ & & & & & & & \\
\hline 岂 & & Dellii & & & & $16-2$ & \\
\hline$₫$ & Fasci & niformis & & & & & $10-2$ \\
\hline & & enuis & & $10-2$ & & $17-1 / 18-2$ & $10-5$ \\
\hline
\end{tabular}

Figure 2. Cenozoic coccolith zonation of core samples from Deep Sea Drilling Project Leg 40. The numbers assigned to zonal intervals are core and section numbers of samples examined. Where a zone or subzone is represented in samples from two or more core sections, the highest and lowest are given.

fragmented and solution-thinned. Samples from Cores 3 and 4 (98 to $146 \mathrm{~m})$ are barren or nondiagnostic.

Core 5 (174 to $184 \mathrm{~m})$ contains several Eocene coccolith zones. A diverse lower Nannotetrina quadrata Zone assemblage in Sample 361-5-1, 20-21 cm (174 m), contains Rhabdosphaera gladius, a middle Eocene marker species generally missing in deep-sea cores. Other species present include Chiasmolithus grandis, $C$. solitus, Coccolithus staurion, Cyclicargolithus pseudo- gammation, Discoaster mirus, $D$. nonaradiatus, $D$. saipanensis, Ellipsolithus lajollaensis, Helicosphaera lophota, Nannotetrina quadrata, Reticulofenestra dictyoda, Sphenolithus radians, and Zygolithus dubius. The Rhabdosphaera inflata Subzone of Sample 361-5-4, $49-50 \mathrm{~cm}(176 \mathrm{~m})$, contains exceptionally large numbers of both Chiasmolithus solitus and Discoaster sublodoensis; Rhabdosphaera inflata is scarce. Similar domination of an $R$. inflata Subzone assemblage occurs 


\begin{tabular}{|c|c|c|c|}
\hline $\begin{array}{c}\text { Site } 360 \\
\text { Sample }\end{array}$ & $\underset{\text { Depth }}{(\mathrm{m})}$ & $\begin{array}{c}\text { Discoaster/ } \\
\text { Chiasmolithus } \\
\text { Ratio }\end{array}$ & Age \\
\hline $30-3,9-11 \mathrm{~cm}$ & 472 & $17 / 83$ & \multirow{4}{*}{ Oligocene } \\
\hline $31-3.49 .50 \mathrm{~cm}$ & 492 & $1 / 99$ & \\
\hline $35-1,70-71 \mathrm{~cm}$ & 564 & $36 / 64$ & \\
\hline $35.3,49.50 \mathrm{~cm}$ & 567 & $44 / 56$ & \\
\hline $36-1,49-50 \mathrm{~cm}$ & 574 & $48 / 52$ & \multirow{4}{*}{$\begin{array}{l}\text { Late } \\
\text { Eocene }\end{array}$} \\
\hline $37.2,49-50 \mathrm{~cm}$ & 593 & $77 / 23$ & \\
\hline $38-1,49-50 \mathrm{~cm}$ & 612 & $89 / 11$ & \\
\hline $40-2,49-50 \mathrm{~cm}$ & 651 & $86 / 14$ & \\
\hline
\end{tabular}

Figure 3. Decrease in the Discoaster/Chiasmolithus ration in dicates cooling conditions from the late Eocene to Oligocene at Site 360.

in Sample 264A-4-5, 60-61 cm (155 m), from a site at lat $34^{\circ} 58.13^{\prime} \mathrm{S}$ off southwestern Australia (Bukry, 1975b). The lowest sample, 361-5-6, 49-50 $\mathrm{cm}(179 \mathrm{~m})$, is assigned to the Discoaster lodoensis Zone; Chiasmolithus grandis and Discoaster lodoensis are common; Coccolithus crassus is scarce; and there are no Discoaster sublodoensis. The same assemblage occurs in Sample $361-6-2,49-50 \mathrm{~cm}(205 \mathrm{~m})$, but the topmost sample of Core 7, 361-7-1, 78-79 cm (231 m), contains the younger $R$. inflata Subzone. The small recovery (less than one $\mathrm{m}$ ) in junction with a skip-coring program suggests a probable in-hole slump.

Solution-resistant Fasciculithus involutus dominates the strongly dissolved upper Paleocene assemblage in Sample 361-9-2, 9-10 cm $(260 \mathrm{~m})$. The next most common species are Discoaster mohleri and D. multiradiatus; placoliths are scarce.

The Danian age of the oldest sample examined, 361$10-2,49-50 \mathrm{~cm}(270 \mathrm{~m})$, is indicated by the occurrence of Chiasmolithus sp. cf. C. danicus, Coccolithus pelagicus s. ampl., Cruciplacolithus tenuis, Markalius inversus, and Zygodiscus sigmoides.

\section{Site 362}

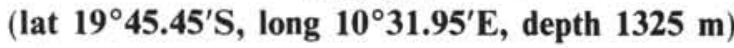

Site 362 , on the Frio Ridge where the Walvis Ridge joins the continental margin of southwest Africa, was cored to date significant regional acoustic reflector horizons. Cenozoić coccolith assemblages, including an Oligocene Braarudosphaera chalk sequence, range from lower Eocene to Holocene. Silicoflagellates are prominent in upper Miocene to Holocene samples, and are distinctly similar to North Atlantic (Leg 37) and North Pacific (Leg 32) associations.

Discoasters are generally sparse through the Pliocene of Cores 5 to 13 (74 to $158 \mathrm{~m})$, which impedes application of low-latitude zonations. This indication of cool-water conditions is supported by the high percentages of Distephanus (26\% to $64 \%$ ) among the silicoflagellates. Discoasters are more common in the Miocene, and this aids in recognition of numerous subzones. The appearance of Discoaster berggrenii in Core 26 and Amaurolithus delicatus in Core 23, and the disappearance of Discoaster quinqueramus in Core 20, were used to identify the two subzones of the Discoaster quinqueramus Zone. Discoaster loeblichii in Sample 362$27-3,49-51 \mathrm{~cm}(410 \mathrm{~m})$, was used to indicate the upper part of the Discoaster neohamatus Zone.

A sparse occurrence of Cyclococcolithina macintyrei in Sample 362-37-3, 49-50 cm (619 m), may indicate the lower Sphenolithus heteromorphus Zone, but the dominance of Discoaster deflandrei among the discoasters is more typical of the Helicosphaera ampliaperta Zone. The name-giving species Helicosphaera ampliaperta also outnumbers $C$. macintyrei, an indication that the upper part of the $H$. ampliaperta Zone was sampled.

Sphenolithus ciperoensis occurs with Dictyococcites bisectus and Helicosphaera recta in Sample 362A-2A-3, $49-50 \mathrm{~cm}(800 \mathrm{~m})$, an association of the upper Sphenolithus ciperoensis Zone. The presence of $S$. ciperoensis and $S$. distentus in Sample 362A-3A-3, $49-50 \mathrm{~cm}(838$ $\mathrm{m})$ indicates the lower $S$. ciperoensis Zone. This sample is further distinguished by the frequent occurrence of Rhabdosphaera procera, as rhabdolithid coccoliths are generally missing from upper Oligocene oceanic assemblages.

Large, thick pentaliths of Braarudosphaera sp. cf. $B$. bigelowii and $B$. rosa are frequent to abundant in several samples from Cores $4 \mathrm{~A}$ and $5 \mathrm{~A}(872$ to $920 \mathrm{~m})$. The greatest abundances are in beds termed Braarudosphaera chalks, which contain Oligocene Sphenolithus distentus Zone coccolith assemblages. Braarudosphaera are sparser in other Oligocene zones, however; even within the $S$. distentus Zone, some levels lack Braarudosphaera, as for example Sample 362A-4A-5, 43-44 cm $(878 \mathrm{~m})$. In the core logs of the Initial Core Description for Leg 40, shipboard scientists illustrate 18 distinct Braarudosphaera beds of bluish white limestone in Core $4 \mathrm{~A}$ and 16 in Core 5A. The Braarudosphaera beds, which range from 10 to $150 \mathrm{~cm}$ thick, are separated by drab gray marls of similar thickness.

Coccolith assemblages through the chalk and marl intervals are rather uniform. The only paleontologically significant difference between the two units is dilution of the normal assemblage by pentaliths and pentalith fragments of Braarudosphaera in the chalk beds (Plates 2 and 3). Pentaliths of a related genus, Micrantholithus, occur commonly only in Sample $362 \mathrm{~A}-5 \mathrm{~A}-1,82-83 \mathrm{~cm}$ (911 $\mathrm{m})$, which is further distinguished by having more than half of the Braarudosphaera specimens intact, rather than in the typical largely disaggregated state.

The general coccolith assemblage differs from those typical of open ocean only by the slightly more common occurrence of Helicosphaera. A representative assemblage, disregarding the pentalith species, includes Chiasmolithus altus, Coccolithus eopelagicus, C. pelagicus, Cyclicargolithus abisectus, C. floridanus, Dictyococcites bisectus, D. scrippsae, Discoaster deflandrei, D. tanii, Helicosphaera compacta, $H$. euphratis, $H$. intermedia, $H$. perch-nielsenasae, $H$. wilcoxonii, Reticulofenestra $\mathrm{sp}$. cf. $R$. gartneri, Sphenolithus distentus, $S$. moriformis, $S$. predistentus, and Zygrhablithus bijugatus.

The distribution of Braarudosphaera chalk beds at DSDP Sites 14, 17, 19, 20, 22, and 362 suggests an essentially regional aberration of surface water 
conditions during the late Oligocene in the South Atlantic Ocean. The episode at Site 362 was prolonged through the Sphenolithus distentus Zone. It was cyclical; at least 34 Braarudosphaera chalk beds, representing a maximum interbed period of 100,000 years or less, are recorded at Site 362. Other isolated Braarudosphaera chalks are at Oceanographer Canyon (Alvin-2698; lat $40^{\circ} 15^{\prime} \mathrm{N}$, long $68^{\circ} 06^{\prime} \mathrm{W}$ ) in the North Atlantic, at Site 209 in the western Pacific, and at Site 363 in the South Atlantic.

Of the various conditions that might account for the great abundance of a typical nearshore fossil in the open ocean (Roth, 1974), salinity and nutrient supply seem more important than temperature. Modern Braarudosphaera occur in significant numbers off Maine and Panama in marine waters of lower than normal salinity (Gran and Braarud, 1935; Smayda, 1966). A sessile life phase (Takayama, 1972; Bybell and Gartner, 1972) might explain its high relative abundance in nearshore areas and the thicker Braarudosphaera beds at nearshore sites in the South Atlantic. But this would not directly account for the cyclic mode of deposition and the lack of reworked specimens in deeper water deposits of the South Atlantic.

Inadequate knowledge of the true nature of the organism that produces Braarudosphaera skeletons hampers understanding the anomalous oceanic Braarudosphaera beds. Is it a coccolithophore which blooms only when certain nutrients are optimal, or, is the reverse true-that it is an encystment life stage of an organism that normally lacks a mineralized skeleton, producing a Braarudosphaera skeleton only in response to the withdrawal of some essential nutrient? Although living $B$. bigelowii has been collected for biological study, long-term cultures have not been achieved (Lefort, 1972). Until laboratory-culture studies are done on the life cycle and nutrition of modern Braarudosphaera, interpretations of the Oligocene Braarudosphaera chalk beds are speculative.

The long geological range and conservative, compact skeletal form of Braarudosphaera (Fischer et al., 1967) suggest that it probably is an encystment. Because its greatest modern concentrations are found in marine areas of lower than normal ocean salinity (areas of high coastal runoff, or upwelled water), short-termed lowering of near-surface salinity, or some related factor, may account for the blooms of Braarudosphaera in the South Atlantic (Bukry, 1974). Periodic influx of near surface waters diluted by glacial meltwaters might have contributed to the low salinity pulses (Hsü, personal communication, 1977).

Isthmolithus recurvus is more common is the lower Helicosphaera reticulata Zone than in the underlying Discoaster barbadiensis Zone, but nowhere in such large numbers of specimens as were recorded at Site 360, which is 16 degrees farther south.

Eocene coccolith specimens of Cores 9A to 12A (996 to $1081 \mathrm{~m}$ ) are poorly preserved, owing to diagenetic overgrowth and fragmentation. Coccolith debris is common. The top sample of Core 9A, 362A-9A-1, 107$108 \mathrm{~cm}(997 \mathrm{~m})$, is assigned to the upper Reticulo- fenestra umbilica Zone; but the presence of Dictyococcites bisectus and the scarcity of Chiasmolithus grandis, Reticulofenestra umbilica, Sphenolithus furcatolithoides, and Triquetrorhabdulus inversus suggest a possible lower Discoaster barbadiensis Zone assemblage with reworking.

Triquetrorhabdulus inversus, missing at Site 360 , is present through the middle Eocene at Site 362, indicating relatively warm conditions.

The oldest Cenozoic sample available from Site 362 is lower Eocene. Sample 362A-12A-1, 107-108 cm (1073 $\mathrm{m})$, contains a thickly overgrown assemblage dominated by Zygrhablithus bijugatus and Discoaster barbadiensis. The most common placoliths are Coccolithus crassus and C. magnicrassus. Other taxa present include Campylosphaera dela, Chiasmolithus sp. cf. C. grandis, Coccolithus pelagicus, Discoaster lodoensis, D. sp. cf. D. mirus, and Sphenolithus radians. This is a Discoaster lodoensis Zone assemblage.

\section{Site 363}

(lat $19^{\circ} 38.75^{\prime} \mathrm{S}$, long $9^{\circ} 02.80^{\prime} \mathrm{E}$, depth $2248 \mathrm{~m}$ )

Site 363 , on the north side of the Frio Ridge segment of the Walvis Ridge, was cored to obtain a Mesozoic reference section for this region. Drilling at nearby Site 362 was terminated in the lower Cenozoic because of bit failure. Cenozoic coccolith assemblages recovered at Site 363 range from lower Paleocene to middle Miocene. Coccoliths are abundant, but moderately to heavily etched and overgrown through the Cenozoic interval of Cores 1 to 18 (31 to $335 \mathrm{~m}$ ).

The overlapping ranges of Coccolithus miopelagicus, Cyclicargolithus floridanus (abundant), Discoaster deflandrei, D. exilis, Reticulofenestra pseudoumbilica, Sphenolithus sp. cf. $S$. abies, and Triquetrorhabdulus rugosus in Sample 363-1-1, 49-50 cm (32 m) indicate the middle Miocene Coccolithus miopelagicus Subzone of the Discoaster exilis Zone.

Sample $363-1-5,48-50 \mathrm{~cm}(38 \mathrm{~m})$ contains the youngest known occurrence of the Braarudosphaera chalk in the South Atlantic. Pentaliths and pentalith fragments constitute about half of coccoliths present. Braarudosphaera rosa is more abundant than $B$. bigelowii, and populations of both are roughly 75 per cent fragmented specimens. The coccolith assemblage is assigned to the basal Miocene Discoaster deflandrei Subzone of the Triquetrorhabdulus carinatus Zone. Members of the assemblage include Coccolithus miopelagicus (unusually small centers), $C$. pelagicus, Coronocyclus sp., Cyclicargolithus floridanus (abundant), Discoaster deflandrei (common), Helicosphaera euphratis, H. intermedia (common), Micrantholithus sp. cf. $M$. vesper, Sphenolithus moriformis, Triquetrorhabdulus carinatus, and T. milowii.

Large but more meager Braarduosphaera in the basal Sphenolithus distentus Zone of Samples 363-6-2, 49-50 $\mathrm{cm}(127 \mathrm{~m})$ and $363-7-1,49-50 \mathrm{~cm}(145 \mathrm{~m})$ occur with Peritrachelina joidesa and common Zygrhablithus bijugatus, suggesting shallow-marine conditions. Sphenolithus distentus is the most prominent sphenolith in Section 7-1, but a few giant specimens of Sphenolithus pseudoradians are present. 
Etching of coccoliths increases slightly downward through Core 9. The lower sample, 363-9-4, 49-50 cm $(187 \mathrm{~m})$, contains a great abundance of solutionresistant Isthmolithus recurvus and Discoaster nodifer, but lacks any rosette discoasters. It is tentatively assigned to the uppermost Eocene because of the flood of Isthmolithus; the defining species for the Discoaster barbadiensis Zone are not present.

Ortholithid coccolith taxa, such as Zygrhablithus bijugatus, Triquetrorhabdulus inversus, and species of Discoaster are common to abundant through the Eocene. Rarely reported four-rayed specimens of Discoaster martinii occur in Sample 363-11-1, 49-50 cm $(222 \mathrm{~m})$, in an assemblage that also contains scarce Discoaster sp. cf. D. bifax and Reticulofenestra umbilica, and common Chiasmolithus grandis and Sphenolithus furcatolithoides.

The deepest Cenozoic sample, 363-18-2, 49-50 cm $(327 \mathrm{~m})$, has a moderately etched lower Paleocene assemblage including Biantholithus sparsus, Braarudosphaera sp. cf. B. bigelowii, Coccolithus pelagicus s. ampl., Cruciplacolithus tenuis, Markalius inversus, Thoracosphaera operculata, and Zygodiscus sigmoides.

\section{Site 364 \\ (lat $11^{\circ} 34.32^{\prime} \mathrm{S}$, long $11^{\circ} 58.30^{\prime} \mathrm{E}$, depth $2448 \mathrm{~m}$ )}

Site 364 is on the continental rise flanking the Angola Basin. The Cenozoic section of Cores 1 to 10 (8 to 359 $\mathrm{m})$ was discontinuously cored, and lower Paleocene to Holocene coccolith assemblages were recovered.

Helicosphaera carteri and Gephyrocapsa oceanica are common in Holocene Sample 364-1-3, 49-50 cm (11 m). Samples from Core 2 ( 36 to $46 \mathrm{~m}$ ) are barren.

Tropical lower Pliocene assemblages, as indicated by a great abundance of Discoaster brouweri and D. pentaradiatus, occur through Core 3 (65 to $73 \mathrm{~m}$ ). Some solution thinning of placoliths and fragmentation of discoasters into individual rays are evident. A general lack of Sphenolithus, a tropical indicator, and of siliceous phytoplankton suggests that unusual paleoecologic conditions, not simply temperature, were operating to create the flood of discoasters relative to other coccoliths.

Helicosphaera ampliaperta is scarce and Sphenolithus heteromorphus abundant in the upper lower Miocene Helicosphaera ampliaperta Zone of Sample 364-5-3, 49$50(152 \mathrm{~m})$. Samples from Cores 6 and 7 (197 to $255 \mathrm{~m}$ ) are barren.

A compressed sequence of lower Eocene and Paleocene zones occurs in Cores 8 to 10 ( 283 to $359 \mathrm{~m}$ ). The Discoaster lodoensis Zone of Sample 364-8-3, 49-50 $\mathrm{cm}(287 \mathrm{~m})$, contains Campylosphaera dela, Chiasmolithus grandis, Coccolithus crassus, $C$. cribellum, $C$. sp. cf. C. formosus, C. magnicrassus, Cyclococcolithina? sp. cf. C. gammation, Discoaster barbadiensis, D. lodoensis, $D$. sp. cf. D. mirus, Discoasteroides kuepperi, and Sphenolithus radians. It lacks abundant Zygrhablithus bijugatus, a shallow-water indicator dominant at Site 362. The upper Paleocene Campylosphaera eodela Subzone is characterized by Campylosphaera eodela (common), Chiasmolithus bidens, C. consuetus, Discoaster multiradiatus, D. nobilis, Ellipsolithus macellus. Neochiastozygus chiastus, $N$. distentus, and Toweius craticulus. Lower Paleocene assemblages are more strongly etched than those just described. For example, the Fasciculithus tympaniformis Zone of Sample 364-10$2,49-50 \mathrm{~cm}(351 \mathrm{~m})$, is characterized by resistant placolith rims and species of Fasciculithus including $F$. involutus, $F$. janii, $F$. pileatus, and $F$. tympaniformis.

\section{Site 365}

(lat $11^{\circ} 39.10^{\prime} \mathrm{S}$, long $11^{\circ} 53.72^{\prime} \mathrm{E}$, depth $3018 \mathrm{~m}$ )

No Cenozoic samples were available from this site on the continental rise of the Angola Basin. Coring between 225 and 687 meters subbottom was part of an attempt to directly sample the Aptian salt layer presumed to underlie the basin. See report of shipboard scientists.

\section{NEOGENE SILICOFLAGELLATE CORRELATION}

Silicoflagellates are scarce to common in upper Miocene to Holocene samples from Site 362 on the Frio Ridge. Specimen counts for 14 samples through the 133-meter interval of Cores 1 to 14 indicate the relative abundance and range of stratigraphic and paleoecologic guide fossils (Figure 4).

Several similarities in ranges and abundances of species exist between Site 362 and other Deep Sea Drilling Project sites in the North Atlantic and Pacific oceans. The disappearances of Mesocena circulus, Dictyocha brevispina, and Distephanus boliviensis jimlingii or $D$. boliviensis major, and the first, consistent, common to abundant occurrence of Dictyocha stapedia stapedia are noted in the upper Pliocene to lower Pleistocene at Site 362 and at Site 333 (lat $37^{\circ} \mathrm{N}$ ) in the North Atlantic, Site 310 (lat $37^{\circ} \mathrm{N}$ ) in the North Pacific (Figure 5), and Site 321 (lat $12^{\circ} \mathrm{S}$ ) in the South Pacific.

Another distinctive feature common to the two Atlantic sites is an upper Pliocene acme horizon of Dictyocha perlaevis ornata-38\% in Core 7 at Site 362 and $52 \%$ in Core 2 at Site 333 (Bukry, in press). In regional settings of similar ecology, horizons of shorttermed taxa, such as $D$. perlaevis ornata, may provide useful guides for correlation.

Biostratigraphically, the presence of Dictyocha aculeata in Sample 362-1-4, 49-51 cm (41 m), indicates the Quaternary Dictyocha aculeata Zone. The Pliocene/Pleistocene boundary based on silicoflagellate evidence is not well established for various locations. Coccolith evidence shows this boundary to be within the lower part of Core 4 or the upper part of Core 5 at Site 362 . Several changes in silicoflagellate assemblages occur in or near this interval, including a marked increase in the numbers of Dictyocha stapedia stapedia and the disappearance of Distephanus boliviensis major group. A persistence of Distephanus boliviensis boliviensis from the Pliocene into the Pleistocene here suggests that the first common occurrence of $D$. stapedia stapedia at middle latitudes in the Atlantic is a 


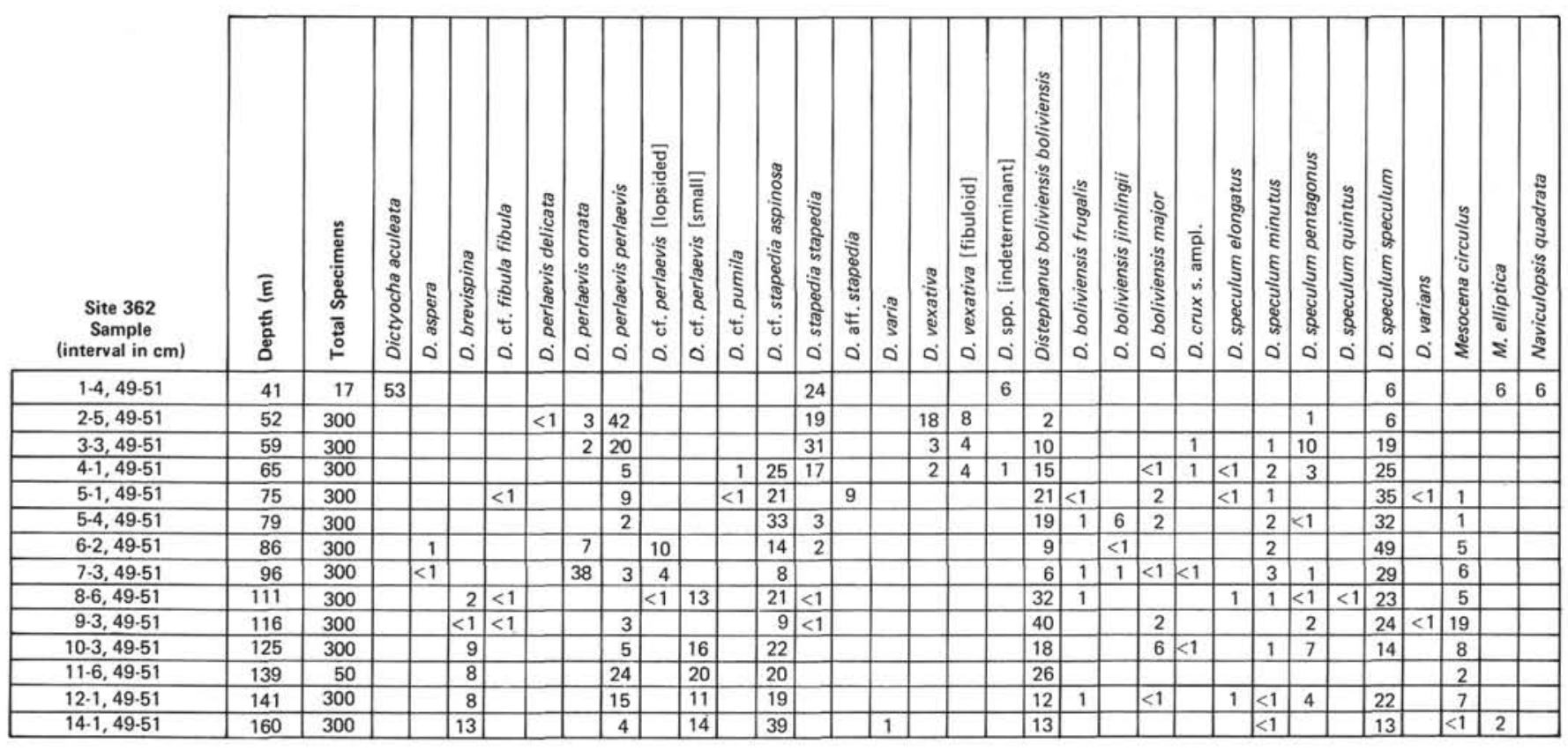

Figure 4. Neogene silicoflagellates at Site 362 recorded as percents. Samples above 65 meters are Quaternary, samples from 75 to 141 meters Pliocene, the sample at 160 meters Miocene or Pliocene.

better guide to the Pliocene/Pleistocene boundary than is the dwindling of $D$. boliviensis boliviensis. Local variations in the degree of upwelling change the relative ranges of both of these taxa, as for example at DSDP Sites 157 and 321 in the Pacific (Bukry, 1976b). The disappearance of Mesocena circulus most closely matches the Pliocene/Pleistocene boundary at several widely separated DSDP sites, including Sites 362,333 , 321,310 , and 157, all of which lie between latitudes $37^{\circ} \mathrm{N}$ to $20^{\circ} \mathrm{S}$ and contain either tropical or transitional assemblages. $M$. circulus disappeared much earlier from Antarctic waters, and is used to mark the upper Miocene there. On the basis of the disappearance of $M$. circulus and the first common occurrence of D. stapedia stapedia, the interval from 52 to 65 meters at Site 362 is assigned to the Dictyocha stapedia stapedia Zone (Bukry, in press), which is Quaternary at Site 362.

The upper Pliocene Distephanus boliviensis boliviensis Zone and lower and upper Pliocene D. boliviensis major Zone of the eastern Pacific are not separable at Site 362. The interval from 75 to 141 meters, which is lower and upper Pliocene on the basis of coccolith evidence, has common to abundant $D$. boliviensis boliviensis and a few $D$. boliviensis major throughout. The whole interval is tentatively called the $D$. boliviensis major Zone. The disappearance of Dictyocha brevispina within the interval, and the acme of $D$. perlaevis ornata near the top, match the occurrences of DSDP Site 333 in the North Atlantic (Bukry, in press).

The basal silicoflagellate Sample 362-14-1, 49-51 cm $(160 \mathrm{~m})$, is poorly diagnostic. The few specimens of Mesocena elliptica appear to be derived from the coeval Dictyocha brevispina population, on the basis of size and surface texture. Dictyocha varia is an evolutionary development from $D$. pulchella, and as such could suggest the upper Miocene or lower Pliocene. No zone is assigned.

\section{SILICOFLAGELLATE TAXONOMY}

A high degree of morphologic variability in the genus Dictyocha at Site 362 prompts a large number of compared species identifications (Figure 4). Coastal assemblages contain a higher proportion of aberrant contorted silicoflagellates than assemblages from far offshore. The domination of lopsided specimens among the Dictyocha perlaevis group in Sample 362-6-2, 49-50 $\mathrm{cm}(86 \mathrm{~m})$, coincides with the greatest abundance of the cool-water guide species Distephanus speculum speculum. This lopsided Dictyocha is considered to be a phenotypic variation of indeterminate cause, because a few lopsided variants occur in the upper Pliocene of Site 157 in the Panama Basin, where D. speculum speculum is sparse. A decision to distinguish or to lump such forms into the parent stock may make even seemingly detailed species lists highly personalized.

Questions of which name is given priority and how broad or restrictive species concepts should be, all contribute to problems of communication in silicoflagellate taxonomy. For example, what is the significance of relative counts for the Miocene plexus of Dictyocha species having the apical bar aligned with the short axis of the basal ring-D. aspera aspera, D. aspera clinata, D. ausonia, D. brevispina, D. mutabilis, D. pulchella, D. rhombica, or D. varia-when older species lists lumped some or all together? The only way to retrieve the data is to repeat the counts. A system of numerical descriptors for morphologic features based on a hierarchy of structural features would help stabilize nomenclature and make taxonomic lists more widely interpretable. New groupings or interpretations could be made without repeating earlier work.

Two new species and a new combination are described for Leg 40. Illustration references for other cited species are listed in short form. 


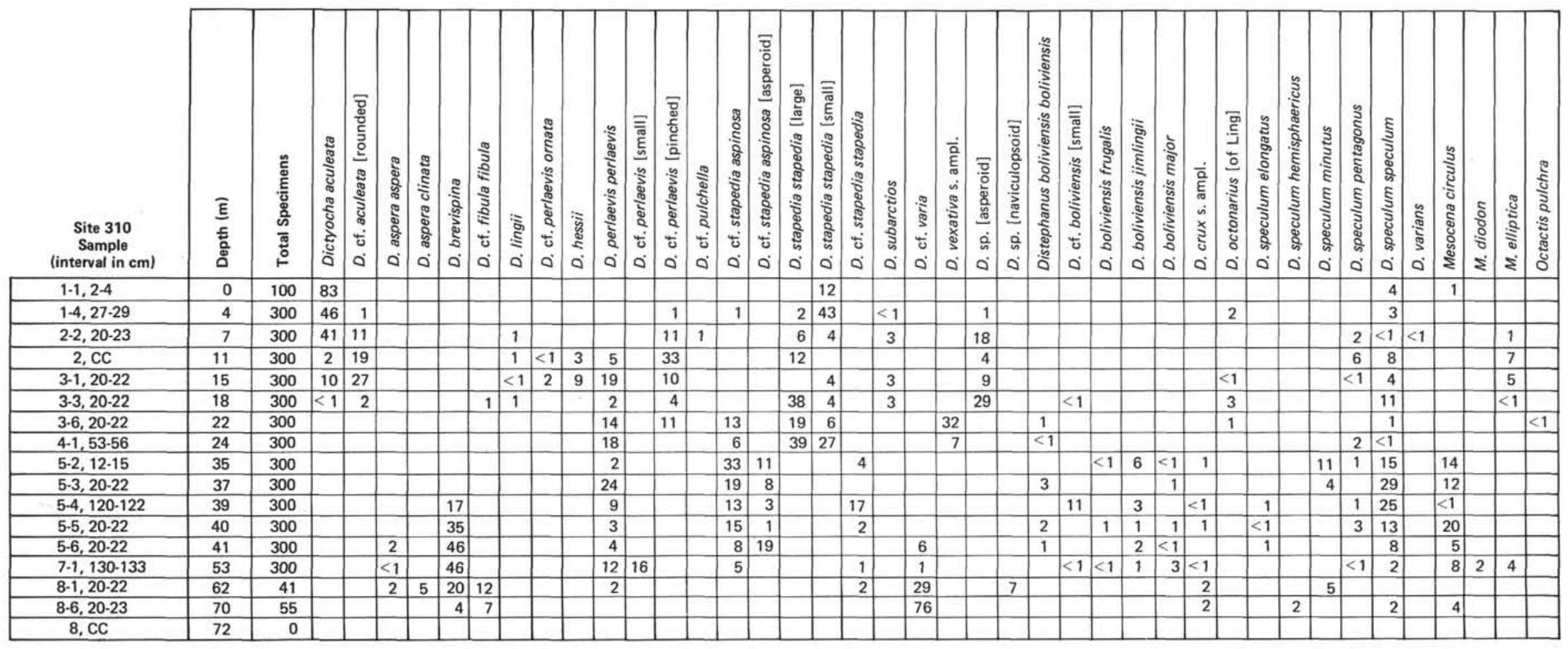

Figure 5. Neogene silicoflagellates at Site 310 recorded as percents. Samples above 24 meters are Quaternary, samples from 35 to 53 meters Pliocene, the samples from 62 to 72 meters upper Miocene. The plexus of warm and cool-water taxa of Dictyocha in the Quaternary requires detailed study. 


\section{SYSTEMATIC PALEONTOLOGY}

\author{
Genus DICTYOCHA Ehrenberg, 1837
}

Dictyocha hessii n. sp.

Dictyocha sp. cf. D. aspera Lemmermann, Dumitrica, 1973 (in part), Deep Sea Drilling Proj. Initial Repts., v. 13, p. 907, pl. 7, fig. 47.

Dictyocha lingi Dumitrica, Dumitrica, 1973 (in part), Deep Sea Drilling Proj. Initial Repts., v. 21, p. 848, pl. 3, fig. 4.

Description: Dictyocha hessii has a small to moderate basal ring that is finely apiculate along the periphery. The apical bar is moderate and oriented perpendicular to the major axis. Spines are moderate and the basal ring is slightly elongate and scalloped. Basal pikes are small and located at or beside the strut-ring junctions.

Remarks: Dictyocha hessii is distinguished from $D$. lingii by a more scalloped outline instead of a more continuous ellipse, also by the apical structure which is of regular thickness. $D$. hessii is distinguished from $D$. perlaevis ornata by the apical bar orientation and by the irregular and more abundant apiculation of the basal ring. $D$. hessii is distinguished from other small to moderate asperoid taxa, such as $D$. pulchella, $D$. varia, and $D$. vexativa, by its apiculate periphery.

Occurrence: The holotype and isotypes of Dictyocha hessii are from the lower Quaternary of Site 128 in the Mediterranean Sea. Other specimens occur in the Quaternary at Sites 206, 310, and 412 which extends the range of $D$. hessii through the Atlantic and Pacific Oceans. It is sparse to common at these sites.

Size: Maximum internal diameter 25 to $45 \mu \mathrm{m}$; holotype ( $28 \mu \mathrm{m})$.

Holotype: Plate 7, figure 6 of Dumitrica, 1973, DSDP Volume 13.

Isotypes: Plate 7, figures 4, 5, 7 of Dumitrica, 1973, DSDP Volume 13.

Type locality: Mediterranean Sea, Sample 128-11-3, 148-150 cm $(475 \mathrm{~m})$.

Dictyocha pumila (Ciesielski) n. comb.

Dictyocha fibula var. pumila Ciesielski, 1975, v. 28, p. 656, pl. 5 . fig. 5-10; pl. 6, fig. 1, ?2.

Remarks: Dictyocha pumila is a distinctive fibuloid species from Antarctic waters (Ciesielski, 1975). It has a basal ring that is slightly and unevenly, convexly flexed. $D$. pumila is distinguished from the $D$. fibula group by its asymmetric strut placement and canted apical bar. It is distinguished from the $D$. perlaevis and $D$. stapedia groups by irregular outline and curved spines. In terms of size and proportions, D. pumila is most similar to D. stapedia aspinosa; it is distinguished by its irregular flexed outline. And Pliocene populations of D. stapedia aspinosa have a propensity to develop strut pikes.

Dictyocha vexativa n. sp.

(Plate 1, Figures 10-14)

Description: Dictyocha vexativa has a small, very slightly elongate and rounded, rhomboid basal ring. Spines are straight and short to moderate in length. Four basal pikes are slightly offset from the strut junctures, clockwise in apical view. The apical bar is short, axially alined and the strut-bar-strut outline is rounded. The struts appear to narrow slightly away from the bar, toward the basal ring. One or more of the struts are usually curved in apical view. Asperoid and fibuloid forms occur.

Remarks: Dictyocha vexativa is distinguished from $D$. pulchella by its more elongate and less rounded basal ring. It is distinguished from $D$. brevispina by its smaller size, and from D. aspera by its more nearly $\mathrm{H}$-shaped apical structure. The tapering, slightly curved struts and short apical bar help distinguish $D$. vexativa from other taxa.

Occurrence: Dictyocha vexativa was first recorded in the Quaternary of DSDP Site 310 in the North Pacific. It was thought to be a local phenotype because substantial Quaternary populations of small asperoid Dictyocha spp. were unknown. However, the occurrence of the same form in the Quaternary at Site 362 suggested a potential value for this species in Quaternary stratigraphy and paleoecology of middle latitude sites.

Size: Maximum internal diameter 22 to $28 \mu \mathrm{m}$; holotype $22 \mu \mathrm{m}$.

Holotype: USNM 240292 (Plate 1, Figures 12, 13).

Isotypes: USNM 240293 and 240294.

Type locality: Southeastern Atlantic Ocean, Sample 362-4-1, 49$51 \mathrm{~cm}(65 \mathrm{~m})$.

\section{ILLUSTRATION REFERENCES FOR SPECIES CITED}

Dictyocha aculeata (Lemmermann)-Perch-Nielsen, 1975

D. aspera aspera (Lemmermann)-Bukry, 1973

D. aspera clinata Bukry-Bukry, $1975 \mathrm{c}$

D. brevispina (Lemmermann)-Bukry, 1976b

D. fibula fibula Ehrenberg-Ling, 1972

D. lingii Dumitrica-Dumitrica, 1973

D. perlaevis delicata Bukry-Bukry, 1976b

D. perlaevis ornata Bukry-Bukry, in press

D. perlaevis perlaevis Frenguelli-Bukry, 1976b

D. pulchella Bukry-Bukry, 1975a

D. stapedia aspinosa Bukry-Bukry, 1976b

D. stapedia stapedia $\mathrm{Haeckel-Bukry,} \mathrm{1976b}$

D. subarctios Ling-Ling, 1970

D. varia Locker-Locker, 1975

Distephanus boliviensis boliviensis (Frenguelli)-Bukry and Foster, 1973

D. boliviensis frugalis Bukry-Bukry, 1975c

D. boliviensis jimlingii Bukry-Bukry, 1975c

D. boliviensis major (Frenguelli)-Bukry and Foster, 1973

D. crux (Ehrenberg)-Ling, 1972

D. speculum elongatus Bukry-Bukry, 1975c

D. speculum hemisphaericus (Ehrenberg)-Locker, 1974

D. speculum minutus (Bachmann)-Ichikawa et al, 1967

D. speculum pentagonus Lemmermann-Ling, 1972

D. speculum quintus (Bukry and Foster)-Bukry and Foster, 1973

D. speculum speculum (Ehrenberg)-Martini, 1971

D. varians (Gran and Braarud)-Bukry, 1976a

Mesocena circulus (Ehrenberg)-Bukry, 1975a

M. diodon Ehrenberg-Bukry, 1975a

M. elliptica (Ehrenberg)-Bukry and Foster, 1973

Naviculopsis quadrata (Ehrenberg)-Ling, 1972

Octactis pulchra Schiller-Bukry and Foster, 1973

\section{ACKNOWLEDGMENT}

I thank Dorothy Blackstock for her assistance in assembling and proofing this report. I am grateful to J.A. Barron, U.S. Geological Survey, and P.H. Roth, University of Utah, for constructive comments on the report. The Alvin2689 sample material was kindly provided by M.N. Bramlette, Scripps Institution of Oceanography. The Black Sea sample 1443G, $6 \mathrm{~cm}$, was provided by Frank Manheim, U.S. Geological Survey, from the Woods Hole Oceanographic Institution core collection.

\section{REFERENCES}

Bukry, D., 1973. Coccolith and silicoflagellate stratigraphy, Tasman Sea and southwestern Pacific Ocean, Deep Sea Drilling Project Leg 21. In Burns, R.E. Andrews, J.E. et al. Initial Reports of the Deep Sea Drilling Project, Volume 21: Washington (U.S. Government Printing Office), p. $885-893$.

1974. Coccoliths as paleosalinity indicators-evidence from Black Sea: Am. Assoc. Petrol. Geol. Mem. 20, p. 353-363.

1975a. Silicoflagellate and coccolith stratigraphy, Deep Sea Drilling Project Leg 29. In Kennett, J.P., Houtz, R.E., et al., Initial Reports of the Deep Sea Drilling Project, Volume 29: Washington (U.S. Government Printing Office), p. 845-872.

1975b. Coccolith and silicoflagellate stratigraphy near Antarctica, Deep Sea Drilling Project Leg 28. In Hayes, D., Frakes, L.A., et al., Initial Reports of the Deep Sea Drilling Project, Volume 28: Washington (U.S. Government Printing Office), p. 709-723.

,1975c. Coccolith and silicoflagellate stratigraphy, northwestern Pacific Ocean, Deep Sea Drilling Project Leg 32. In Larson, R.L., Moberly, R., et al., Initial Reports of the Deep Sea Drilling Project, Volume 32: Washington (U.S. Government Printing Office), p. 677-701.

1976a. Cenozoic silicoflagellate and coccolith stratigraphy, South Atlantic Ocean, Deep Sea Drilling 
Project Leg 36. In Hollister, C.D., Craddock, C., et al., Initial Reports of the Deep Sea Drilling Project, Volume 35: Washington (U.S. Government Printing Office), p. $885-917$.

, 1976b. Silicoflagellate and coccolith stratigraphy, southeastern Pacific Ocean, Deep Sea Drilling Project Leg 34. In Hart, S.R., Yeats, R.S., et al., Initial Reports of the Deep Sea Drilling Project, Volume 34: Washington (U.S. Government Printing Office), p. 715-736.

, in press. Coccolith and silicoflagellate stratigraphy, central North Atlantic Ocean, Deep Sea Drilling Project Leg 37. In Aumento, F., Melson, W.G., et al., Initial Reports of the Deep Sea Drilling Project, Volume 37: Washington (U.S. Government Printing Office), p.

Bukry, D. and Foster, J.H., 1973. Silicoflagellate and diatom stratigraphy, Leg 16, Deep Sea Drilling Project. In van Andel, T.H., Heath, G.R., et al., Initial Reports of the Deep Sea Drilling Project, Volume 16: Washington (U.S. Government Printing Office), p. 815-871.

Bybell, L. and Gartner, S., 1972 [1973]. Provincialism among mid-Eocene calcareous nannofossils: Micropaleontology, v. 18 , p. $319-336$

Ciesielski, P.F., 1975. Biostratigraphy and paleoecology of Neogene and Oligocene silicoflagellates from cores recovered during Antarctic Leg 28, Deep Sea Drilling Project. In Hayes, D., Frakes, L.A., et al., Initial Reports of the Deep Sea Drilling Project, Volume 28: Washington (U.S. Government Printing Office), p. 625-691.

Dumitrica, P., 1973. Paleocene, late Oligocene and postOligocene silicoflagellates in southwestern Pacific sediments cored on DSDP Leg 21. In Burns, R.E. Andrews, J.E., et al., Initial Reports of the Deep Sea Drilling Project, Volume 21: Washington (U.S. Government Printing Office) p. 837-883.

Fischer, A.G., Honjo, S., and Garrison, R.E., 1967. Electron micrographs of limestones and their nannofossils: Princeton Monogr. Geol. Paleontol., Mon. 1, p. 1-141.

Gran, H.H., and Braarud, T., 1935. A quantitative study of the phytoplankton in the Bay of Fundy and the Gulf of Maine (including observations on hydrography, chemistry and turbidity): J. Biol. Board Canada, v. 1, p. 280-467.

Ichikawa, W., Shimizu, I., and Bachmann, A., 1967. Fossil silicoflagellates and their associated uncertain forms in
Iida Diatomite, Noto Peninsula, Central Japan: Kanazawa Univ. Sci. Rept., v. 12, p. 143-172.

Lefort, F., 1972. Quelques caractères morphologiques de deux espèces actuelles de Braarudosphaera (Chrysophycées, Coccolithoracées): Botaniste, v. 55, p. 81-93.

Ling, H.Y., 1970. Silicoflagellates from central North Pacific core sediments: Am. Paleontol. Bull., v. 58, p. 85-129. , 1972. Upper Cretaceous and Cenozoic silicoflagellates and ebridians: Am. Paleontol. Bull. v. 62, p. $135-229$.

Locker, S., 1974. Revision der Silicoflagellaten aus der Mikrogeologischen Sammlung von C.G. Ehrenberg: Eclog. Geol. Helv., v. 67, p. 631-646.

1975. Dictyocha varia sp. n., eine miozäne Silicoflagellaten-Art mit kompliziertem Variationsmodus: Zeitschr. Geol. Wiss., Berlin, v. 3, p. 99-103.

Martini, E., 1971. Neogene silicoflagellates from the equatorial Pacific. In Winterer, E.L., Riedel, W.R., et al., Initial Reports of the Deep Sea Drilling Project, Volume 7: Washington (U.S. Government Printing Office), p. 16951708.

Perch-Nielsen, K., 1975. Late Cretaceous to Pleistocene silicoflagellates from the southern southwest Pacific, DSDP Leg 29. In Kennett, J.P., Houtz, R.E., et al., Initial Reports of the Deep Sea Drilling Project, Volume 29: Washington (U.S. Government Printing Office), p. 677721.

Roth, P.H., 1974. Calcareous nannofossils from the northwestern Indian Ocean, Leg 24, Deep Sea Drilling Project. In Fisher, R.L., Bunce, E.T., et al., Initial Reports of the Deep Sea Drilling Project, Volume 24: Washington (U.S. Government Printing Office), p. 969-994.

Savin, S.M., Douglas, R.G., and Stehli, F.G., 1975. Tertiary marine paleotemperatures: Geol. Soc. Am. Bull., v. 86, p. 1499-1510.

Smayda, T.J., 1966. A quantitative analysis of the ecological conditions and the phytoplankton dynamics at $8^{\circ} 45^{\prime} \mathrm{N}, 79^{\circ} 23^{\prime} \mathrm{W}$ from November 1954 to May 1957: Inter-Am. Tropical Tuna Comm. Bull., v. 11, p. 353-612.

Takayama, T., 1972. A note on the distribution of Braarudosphaera bigelowi (Gran and Braarud) Deflandre in the bottom sediments of Sendai Bay, Japan: Paleont. Soc. Japan Trans. Proc., no. 87, p. 429-435. 
PLATE 1

Silicoflagellates from DSDP Leg 40

Figure 1, magnification $500 \times$; scale bar equals $10 \mu \mathrm{m}$; Figures 2-16, magnification $800 \times$; scale bar equals $10 \mu \mathrm{m}$.

Figure $1 \quad$ Dictyocha sp. cf. D. brevispina (Lemmerman).

Aberrant mimic of Mesocena elliptica.

Sample 362-14-3, 49-51 cm (163 m).

Figure 2, 3 Dictyocha sp. cf. D. brevispina (Lemmermann). Aberrant mimic of Paleocene Corbisema disymmetrica disymmetrica.

Sample 362-14-1, 49-51 cm (160 m).

Figure $4 \quad$ Dictyocha sp. cf. D. perlaevis Frenguelli.

Small form.

Sample 362-10-3, 49-51 cm (125 m).

Figures 5,6 Dictyocha sp. cf. D. perlaevis Frenguelli.

Lopsided form.

5. Sample $362-6-2,49-51 \mathrm{~cm}(86 \mathrm{~m})$.

6. Sample $362-7-3,49-51 \mathrm{~cm}(96 \mathrm{~m})$.

Figures 7,8 Dictyocha perlaevis ornata Bukry. Sample 362-6-2, $49-51 \mathrm{~cm}(86 \mathrm{~m})$.

Figure 9 Dictyocha sp. cf. D. stapedia aspinosa Bukry. Less H-shaped apical structure than Dictyocha vexativa.

Sample 362-4-1, 49-51 cm (65 m).

Figures 10-14 Dictyocha vexativa $\mathrm{n} . \mathrm{sp}$.

10, 11. USNM 240293, Sample 362-4-1, 49-51 cm $(65 \mathrm{~m})$.

12, 13. Holotype, USNM 240292, Sample 362-4$1,49-51 \mathrm{~cm}(65 \mathrm{~m})$.

14. USNM 240294, Sample $362-2-5,49-51 \mathrm{~cm}(52$ $\mathrm{m})$.

Figure $15 \quad$ Distephanus boliviensis boliviensis (Frenguelli). Aberrant specimen; apical ring unjoined by three struts.

Sample $362-5-4,49-51 \mathrm{~cm}$ (79 m).

Figure $16 \quad$ Mesocena circulus (Ehrenberg).

Recurved form.

Sample 362-6-2, $49-51 \mathrm{~cm}$ (86 m). 


\section{PLATE 1}
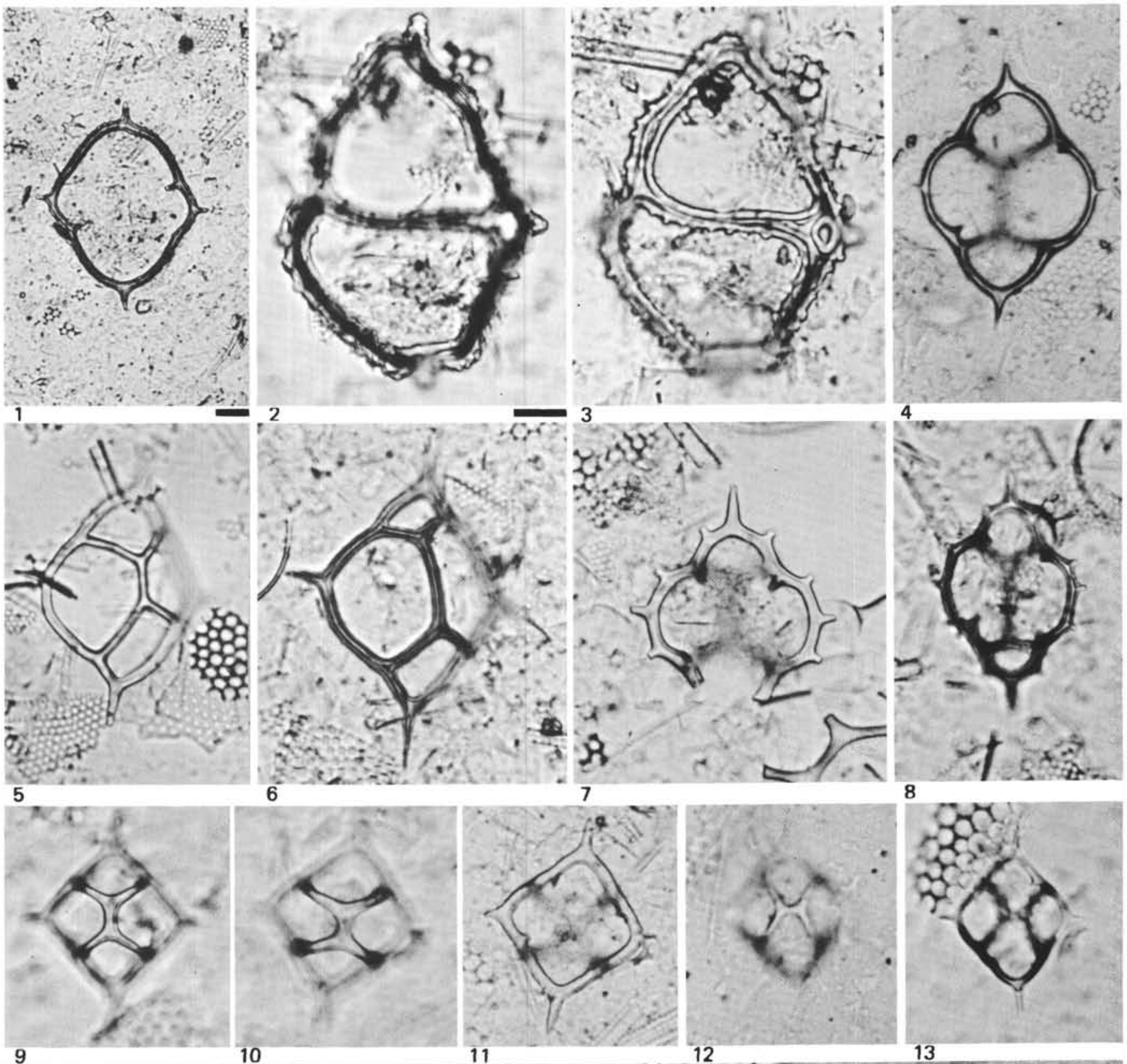

$$
6
$$
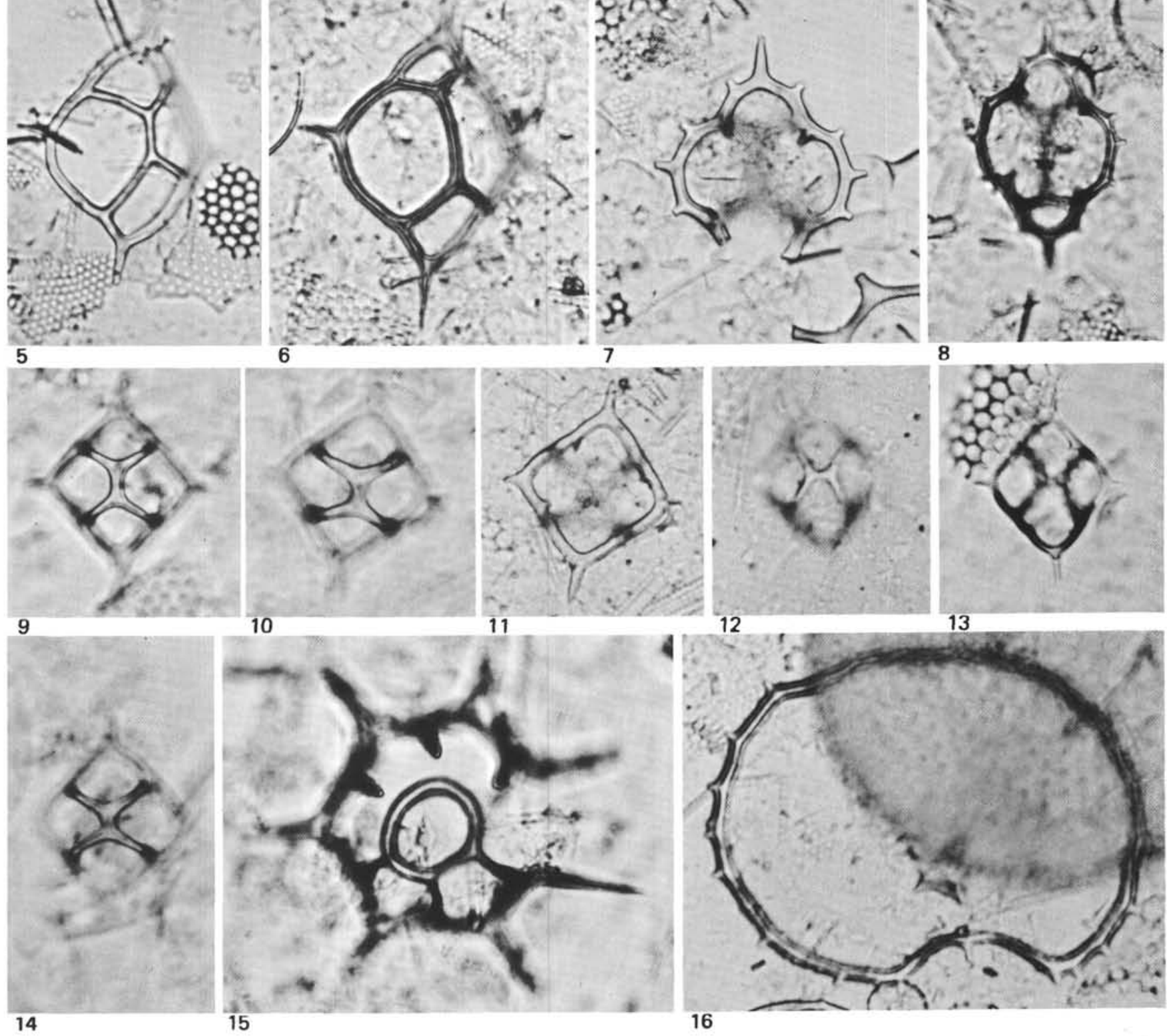
PLATE 2

Braarudosphaera-rich, deep-sea sediment from DSDP Sites 22, 362, 363, and Alvin-2698 in the Atlantic Ocean.

Figures 1-3, magnification $500 \times$; scale bar equals $10 \mu \mathrm{m}$;

Figure 4, magnification $2500 \times$; scale bar equals $5 \mu \mathrm{m}$;

Figures 5-8, magnification $800 \times$; scale bar equals $10 \mu \mathrm{m}$.

Figures 1,2 Upper Oligocene sediment having abundant intact pentaliths and wedge-shaped fragments of the coccolith species Braarudosphaera rosa. Sample 363-6-2, 49-50 cm (127 m).

1. Cross-polarized photomicrograph (XP).

2. Bright-field photomicrograph (BF).

Figure 3 Abundant Braarudosphaera bigelowii s. ampl. and B. rosa and fragments from a Braarudosphaera chalk bed (BF).

Sample 362A-5A-1, 82-83 cm (911 m).

Figure $4 \quad$ Braarudosphaera rosa from the upper Oligocene of the North Atlantic. Transmission electronmicrograph. Sample Alvin-2698.

Figures 5,6 Sediment rich in Braarudosphaera fragments. Sample Alvin-2698.

5. (BF).

6. (XP).

Figures 7,8 Braarudosphaera rosa specimens and fragments are distinctly larger and thicker than associated coccoliths. Sample 363-6-2, 49-50 cm (127 m).

7. (XP).

8. (BF). 


\section{PLATE 2}

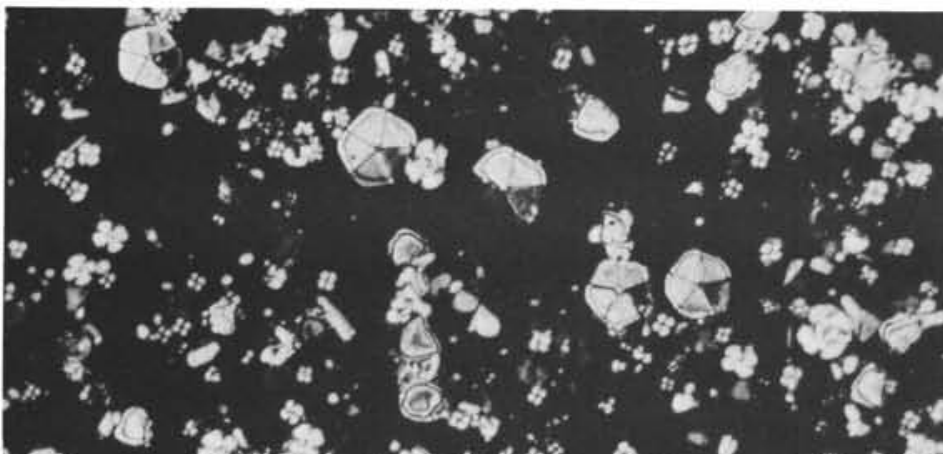

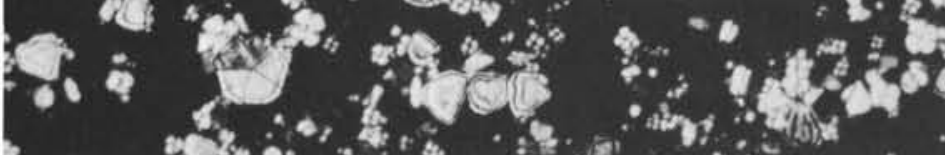

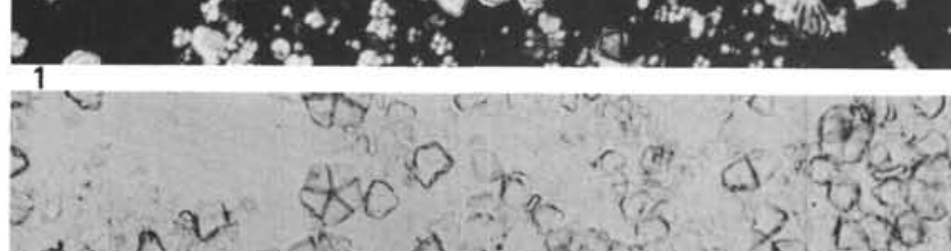

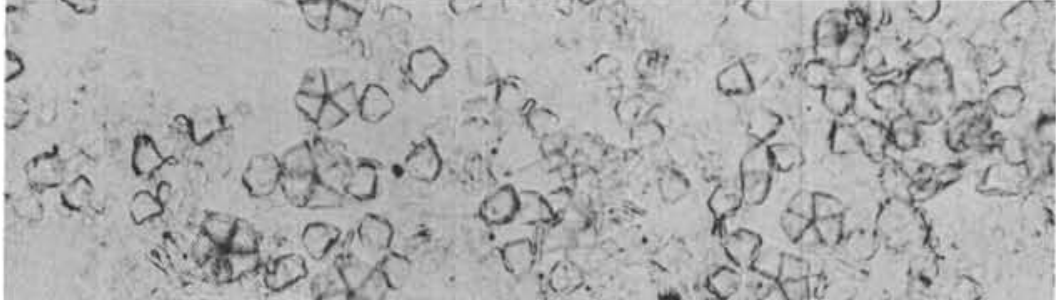

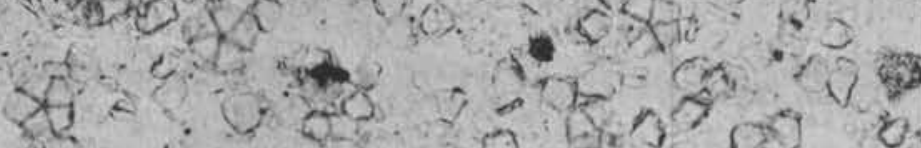

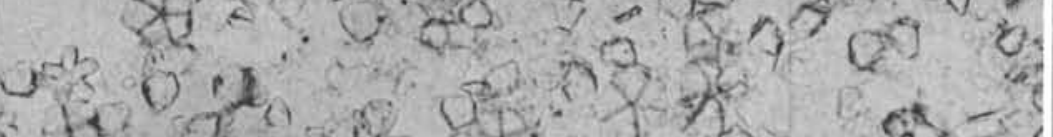

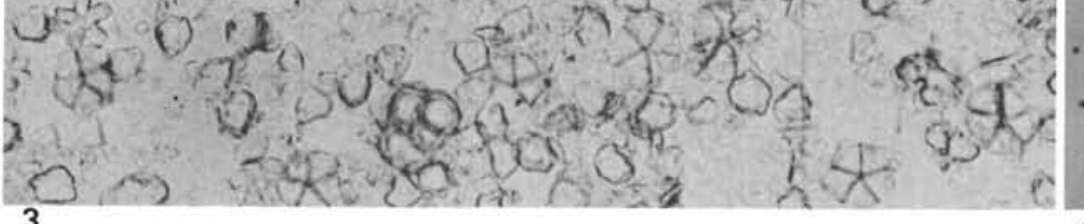

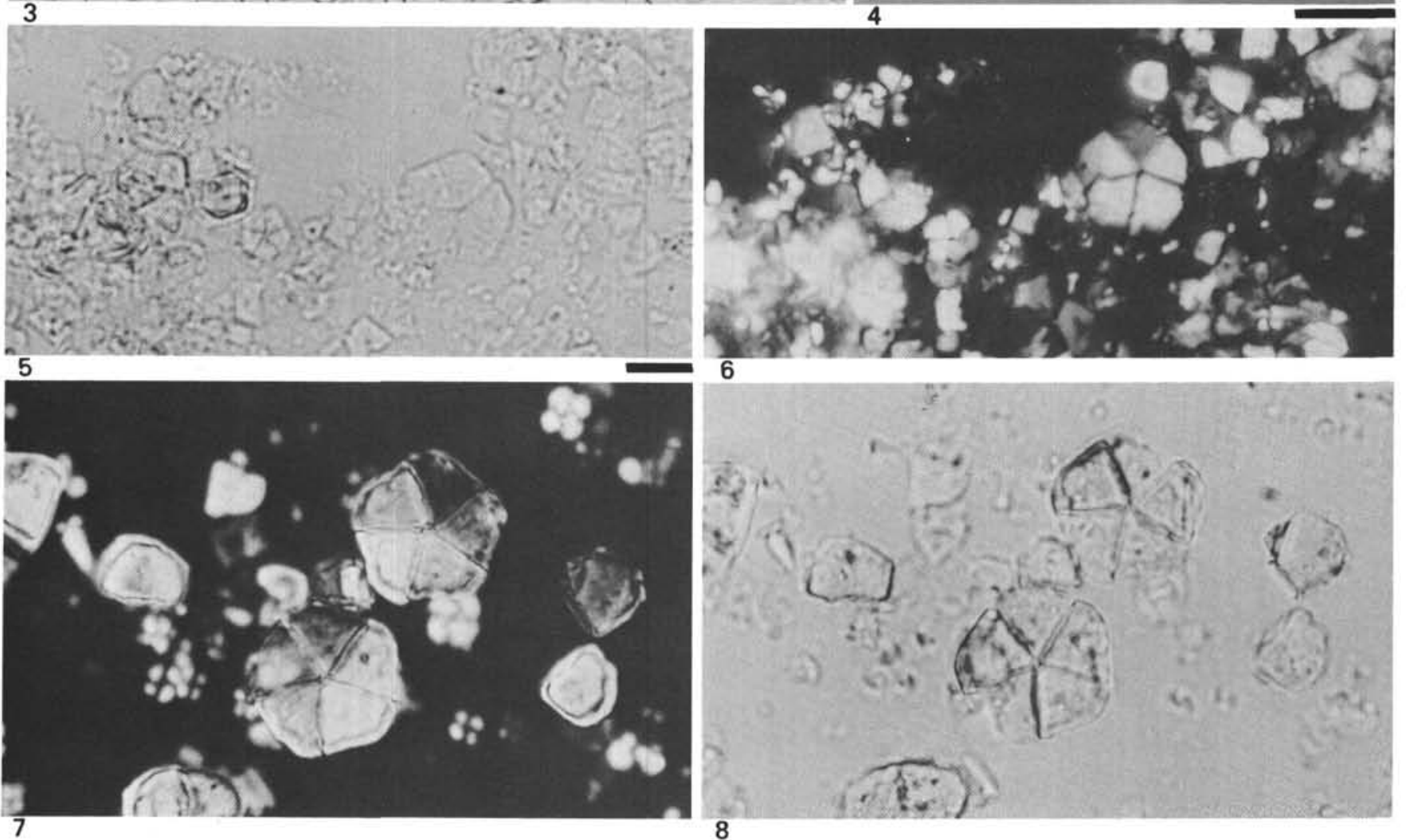


PLATE 3

Braarudosphaera-bearing, deep-sea sediment from DSDP Sites 22, 362,363 , in the Atlantic Ocean, and WHOI Core 1443G, $6 \mathrm{~cm}$, in the Black Sea.

Figures 1, 2, 5, 6, magnification $800 \times$; scale bar equals $10 \mu \mathrm{m}$;

Figures 3, 4 magnification $1000 \times$; scale bar equals $10 \mu \mathrm{m}$;

Figures 7, 8, magnification $500 \times$; scale bar equals $10 \mu \mathrm{m}$.

Figures 1,2 Abundant intact pentaliths and wedge-shaped fragments of the coccolith species Braarudosphaera rosa from an upper Oligocene Braarudosphaera chalk bed. Discoaster deflandrei at lower right. Sample 22-4-1, 74-75 cm (134 m).

1. Cross-polarized photomicrograph (XP).

2. Bright-field photomicrograph (BF).

Figures 3,4 Braarudosphaera bigelowii in a Holocene coccolith ooze from the Black Sea. B. bigelowii, although physically prominent, is much less abundant than the associated oval coccoliths (XP). Sample $1443 \mathrm{G}, 6 \mathrm{~cm}$.

Figures 5,6 Irregularly overgrown and fragmented upper Oligocene Braarudosphaera rosa. Sample 362A$4 \mathrm{~A}-3,21-23 \mathrm{~cm}(875 \mathrm{~m})$.

5. (XP).

6. (BF).

Figures 7,8 Braarudosphaera rosa and fragments, top and side views, in upper Oligocene coccolith assemblage. Sample 363-6-2, 49-50 cm (127 m).

7. (XP).

8. (BF). 


\section{PLATE 3}
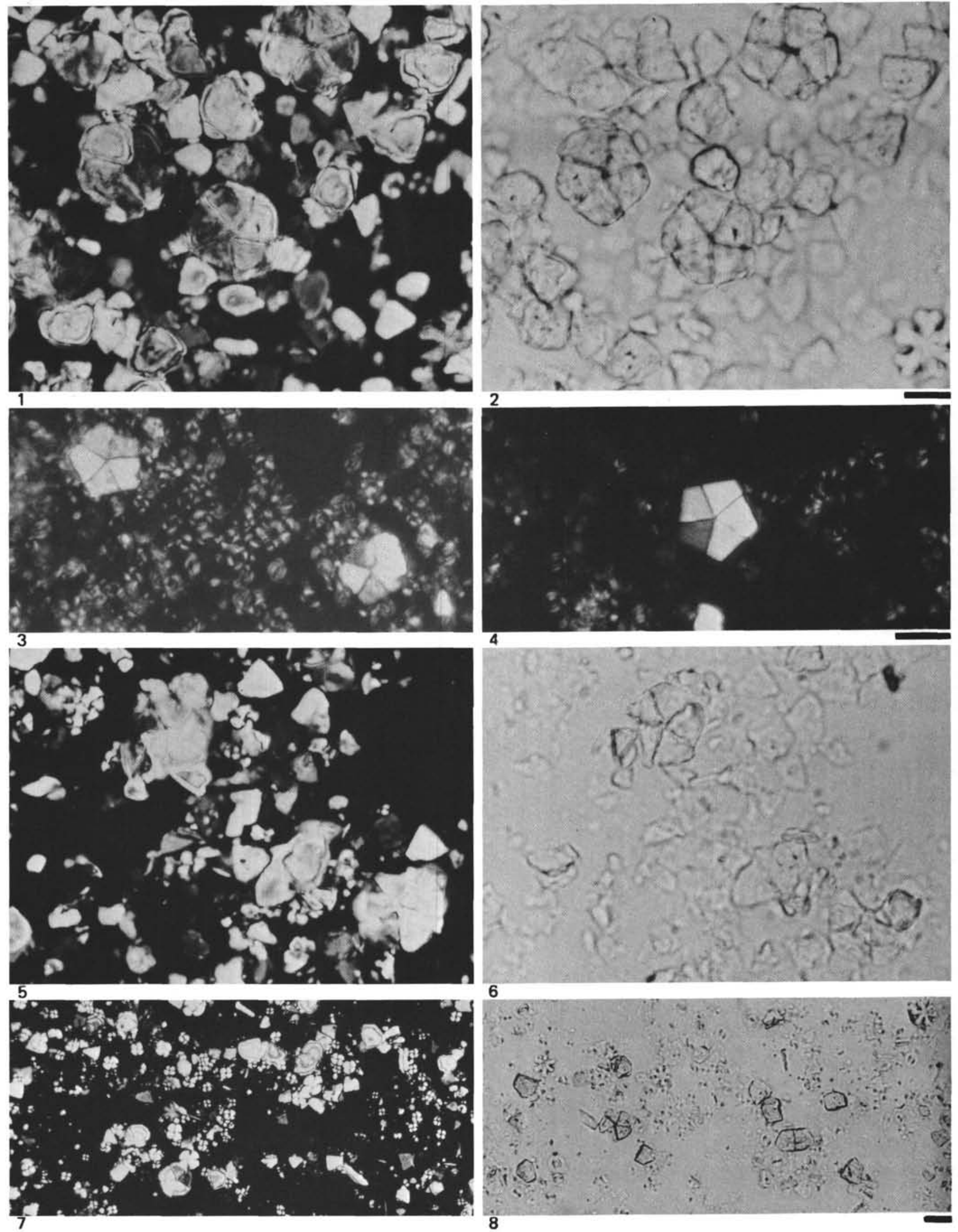